\title{
The Effects of Vitamin D Therapy on Left Ventricular Structure and Function - Are These the Underlying Explanations for Improved CKD Patient Survival?
}

\author{
Adrian Covic $^{\mathrm{a}}$ Luminita Voroneanu ${ }^{\mathrm{a}}$ David Goldsmith ${ }^{\mathrm{b}}$ \\ a Nephrology Clinic, Parhon University Hospital, 'Gr. T. Popa' University of Medicine and Pharmacy, lasi, Romania; \\ ${ }^{\mathrm{b}}$ King's Health Partners, London, UK
}

\section{Key Words}

Chronic kidney disease $\cdot$ Vitamin D deficiency $\cdot$ Cardiac function

\begin{abstract}
Cardiovascular disease is a major cause of death among patients with chronic kidney disease and vitamin D deficiency is a common problem also among these patients. Abnormalities in left ventricular size and function are frequent, as they are encountered in $70-80 \%$ of incident dialysis patients. These alterations develop early in the course of renal disease and their prevalence progresses in parallel with the decline in renal function. This process of left ventricular dilatation with compensatory hypertrophy continues after the institution of dialysis therapy, especially in the first year. The main factors responsible for the progression of left ventricular hypertrophy (LVH) are considered to be blood pressure and anemia, and in patients receiving hemodialysis, the arteriovenous fistula, volume overload and abnormalities in mineral metabolism. This additional potential set of factors related to LVH - mineral and bone metabolism - is intriguing and begs an immediate question: by what possible mechanism can these factors be linked to cardiac morphology? Recent observational studies have indeed indicated that vita-
\end{abstract}

min $D$ treatment was associated with a significant reduction of cardiovascular death among dialysis patients, and a reduction in $\mathrm{LVH}$; in contrast, other studies suggested that excess vitamin D contributes to risk of hypercalcemia and vascular calcification, which is associated with reduced survival and morbidity. This review examines the evidence linking vitamin $\mathrm{D}$ with cardiac structure and function.

Copyright $\odot 2010$ S. Karger AG, Basel

\section{Introduction}

Cardiovascular disease is a major cause of death among patients with chronic kidney disease (CKD) and vitamin $\mathrm{D}$ deficiency is a common problem also among these patients. Abnormalities in left ventricle (LV) size and function are frequent, as they are encountered in $70-80 \%$ of incident dialysis patients [1]. These alterations develop early in the course of renal disease and their prevalence progresses in parallel with the decline in renal function $[2,3]$. This process of LV dilatation with compensatory hypertrophy continues after the institution of dialysis therapy, especially in the first year [4]. The main factors responsible for the progression of left ventricular hypertrophy $(\mathrm{LVH})$ are considered to be blood pressure and

\section{KARGER}

Fax +4161306 1234 E-Mail karger@karger.ch www.karger.com

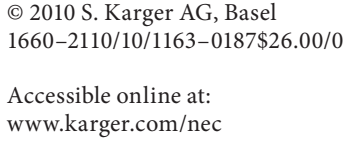

Luminata Voroneanu

Parhon Hospital

Carol 1st Blvd. Nr. 50

RO-700503 Iasi (Romania)

Tel. +40 740605 556, Fax +40 232211 752, E-Mail lumivoro@yahoo.com 
anemia [5], and in patients receiving hemodialysis (HD), the arteriovenous fistula, volume overload and abnormalities in mineral metabolism.

In a very recent cross-sectional analysis of prevalent Chinese patients, a higher prevalence of left ventricular hypertrophy (LVH) was found in HD than in peritoneal dialysis (PD) patients. As left ventricular mass index (LVMI) was associated with high blood pressure and volume overload, it was suggested that PD may preserve a more physiological hemodynamic status even [6]. At the same time, few reports from the literature demonstrate that single interventions (blood pressure control or anemia control) may decrease LV dysfunction. London et al. [7] showed that correction of anemia and strict BP control determined a decrease in LVM - associated with improvement in patient survival. Contradictory data were reported by Foley et al. [8], who found that complete anemia correction (hemoglobin $=13-14 \mathrm{~g} / \mathrm{dl}$ ) did not lead to regression of LVM in established LVH, but might prevent further LV dilatation. In all these studies, the enrolment period occurred before the emergence of the K/DOQI and European Best Practice Guidelines (EBPG) for HD practice. Covic et al. [9] found that strict implementation of EBPG guidelines was associated with an improvement in LV structural and functional parameters, in a significant percentage (61.2\%) of dialysis patients. Anemia, mineral metabolism and blood pressure emerged as the most important determinants for changes in LVMI [9]. This additional potential set of factors related to LVH mineral and bone metabolism - is intriguing and begs an immediate question: by what possible mechanism can these factors be linked to cardiac morphology?

Recent observational studies have indeed indicated that vitamin $\mathrm{D}$ treatment was associated with a significant reduction of cardiovascular death among dialysis patients, and a reduction in LVH [10]; in contrast, other studies suggested that excess vitamin $\mathrm{D}$ contributes to risk of hypercalcemia and vascular calcification, which is associated with reduced survival and morbidity [11].

This review summarizes the available literature regarding the relationship between vitamin $\mathrm{D}$ and cardiovascular disease, especially LVH.

\section{Vitamin D and Vitamin D Receptor in General}

The main source of vitamin $\mathrm{D}$ is de novo synthesis in the skin; under the action of ultraviolet light from sunlight, 7-dehydrocholesterol is converted to vitamin D3. Vitamin D is hydroxylated in the liver by 25 -hydroxylase to 25- $(\mathrm{OH})$ vitamin D. A second, subsequent hydroxylation in the proximal renal tubule by 1-hydroxylase is required to form the active metabolite $1,25(\mathrm{OH})_{2} \mathrm{D}_{3}$. The kidney is the major but not the only site for calcitriol production.

The majority of the molecular action of $1,25(\mathrm{OH})_{2} \mathrm{D}_{3}$ is mediated by the vitamin $\mathrm{D}$ receptor (VDR). The binding of $1,25(\mathrm{OH})_{2} \mathrm{D}_{3}$ to its nuclear VDR leads to VDR activation and heterodimerization with the retinoid $\mathrm{X}$ receptor (RXR) and other cofactors, to form the VDR-RXR complex, which binds to the vitamin $\mathrm{D}$ response element of target genes to regulate gene transcription. The VDR has been found in many tissues, not only in the classical target organs - intestine, kidney, and bone - but also in different cell types, including the immune system. This opens up the possibility of pleiotropic roles and actions for vitamin $\mathrm{D}$ [12]. Additionally, $1,25(\mathrm{OH})_{2} \mathrm{D}_{3}$ appears to bind to one or more cell surface receptors which, through second messenger pathways, mediate certain non-genomic effects [13]. These 2 observations, the widespread expression of the VDR, and the non-classical actions of vitamin $\mathrm{D}$, make this one of the most complex and fastmoving topics in nephrology.

The predominant physiological function of the vitamin $\mathrm{D}$ is to maintain the calcium and the phosphate homeostasis, and this is accomplished by close coordination with parathyroid hormone (PTH). The wide distribution of VDR in almost every tissue provides a molecular basis to explain the beneficial effect of vitamin $\mathrm{D}$ on immune function [14], neuroprotection [15], and cardiac function [16].

Currently, vitamin D deficiency is recognized as endemic in old age and CKD [17]. Several recent studies have identified a high prevalence of vitamin D deficiency and insufficiency in otherwise healthy adults and children living in North America, Europe, and even sundrenched countries. Thomas et al. [18] examined a cohort of 290 consecutively hospitalized patients; they discovered that $57 \%$ had a serum $25(\mathrm{OH}) \mathrm{D}$ below $40 \mathrm{nmol} / \mathrm{l}$ (the lower limit of normal) and $27 \%$ were classed as 'severe' vitamin D deficiency. In the MORE trial, Lips et al. [19] found that serum $25(\mathrm{OH}) \mathrm{D}$ was below $50 \mathrm{nmol} / \mathrm{l}$ in $28.4 \%$ of the postmenopausal women participating in this trial. In a multicenter study of 43 osteoporosis centers from all regions of Italy, including 700 women, values of $25(\mathrm{OH}) \mathrm{D}$ lower than $12 \mathrm{ng} / \mathrm{ml}$ were found in $76 \%$ of study subjects [20].

The major general cause of vitamin $\mathrm{D}$ deficiency is the lack of sufficient sun exposure. Vitamin D deficiency causes poor mineralization of the collagen matrix in 
young children's bones leading to growth retardation and bone deformities known as rickets and will precipitate and exacerbate osteopenia, osteoporosis, and fractures in adults.

Vitamin D deficiency is associated with colon and prostate cancer, type 1 diabetes, hypertension, coronary heart disease, and with alterations in the immune and inflammatory system.

\section{The Relationship between the Vitamin D System and Cardiovascular Abnormalities}

The association between vitamin $\mathrm{D}$ and cardiovascular disease events is widely debated and analyzed in the recent literature. In a very recent cross-sectional study, Pilz et al. [21] measured 25-hydroxyvitamin D $\left[25(\mathrm{OH}) \mathrm{D}_{3}\right]$ levels in 3,299 Caucasian patients who were routinely referred for coronary angiography. They found that vitamin $\mathrm{D}$ deficiency is associated with prevalent myocardial dysfunction, heart failure, and sudden cardiac death. Poole et al. [22] compared serum vitamin $\mathrm{D}$ levels of 44 patients admitted to an acute stroke unit with those of 96 healthy, ambulant elderly subjects; they found that 77 percent of the stroke patients were deficient in vitamin $\mathrm{D}$. In an elegant prospective study, Giovannucci et al. [23], using 18,000 men, showed that low levels of $25(\mathrm{OH}) \mathrm{D}$ are associated with higher risk of myocardial infarction in a graded manner, even after controlling for factors known to be associated with coronary artery disease.

On the other hand, Hsia et al. [24] recently reported that use of calcium and vitamin D supplements was not associated with a reduction in cardiovascular events in the Women's Health Initiative. These apparently discrepant findings could be explained by several factors: the Women's Health Initiative was a fracture-prevention trial and was not designed to evaluate cardiovascular risk, the investigators may have used an inadequate dose of vitamin $\mathrm{D}$ and the baseline $25(\mathrm{OH}) \mathrm{D}$ levels were not measured in the Women's Health Initiative. A more recent meta-analysis of 18 randomized clinical trials, including the Women's Health Initiative, did show that participants randomized to vitamin $\mathrm{D}$ supplementation experienced fewer deaths compared to those randomized to placebo [25].

Although the link between vitamin D deficiency and cardiovascular disease may be, in part, mediated through elevated PTH and calcium-phosphate metabolism, recent scientific evidence showed that vitamin D has 3 major potential protective mechanisms. First, experimental studies indicate that 1,25 -OHD could determine the regulation of the renin-angiotensin axis by directly suppressing renin gene expression. Second, the presence in the cardiac muscle cells of a VDR, a calcitriol-dependent $\mathrm{Ca}^{2+}$ binding protein and a calcitriol-mediated rapid activation of voltage-dependent $\mathrm{Ca}^{2+}$ channels. Consequently, calcitriol administration can normalize the impaired contractility of the myocardium that is observed under experimental vitamin D deficiency. Third, vitamin D deficiency triggers secondary hyperparathyroidism, which then directly promotes cardiac hypertrophy (the direct PTH toxicity hypothesis).

\section{Modulation of the Renin-Angiotensin System by Vitamin D}

Vitamin D may play an important role in reduction of LVH through modulation of the renin-angiotensin system (RAS). The RAS plays a key role in the regulation of volume and blood pressure homeostasis, and over-activation of the RAS is a major pathogenic factor for hypertension, cardiac hypertrophy and atherosclerosis.

In observational and prospective cohort studies, low VDR activation has been associated with increased risk of hypertension, and is inversely correlated with plasma renin activity in patients with essential hypertension. Seasonal changes in blood pressure were described recently, higher blood pressure being associated with winter climate [26]. Vitamin D status, increasing after sun exposure, was associated inversely with blood pressure in a recent epidemiological study of a large normotensive population in the United States [27].

In HD patients, in a small, non-controlled study, intravenous calcitriol led a significant reduction in renin and angiotensin-II levels, and a significant regression of $\mathrm{LVH}$ [28]. These findings were later supported by data from animal and in vitro studies. Li et al. [29], using the vitamin $\mathrm{D}$ receptor knockout mouse model, showed that activated $1,25(\mathrm{OH})_{2} \mathrm{D}_{3}$ inhibits renin secretion from the juxtaglomerular apparatus; they found that plasma angiotensin-II levels, as well as both renin mRNA and protein levels in the kidney, are elevated in vitamin $\mathrm{D}$ receptor knockout mice. More recently, Yuan et al. [30] found that $1,25(\mathrm{OH})_{2} \mathrm{D}_{3}$ in vitro suppresses renin gene transcription by blocking the activity of the cyclic AMP-response element in the renin gene promoter.

Xiang et al. [31] completed the pathogenic link, showing that $1,25(\mathrm{OH})_{2} \mathrm{D}_{3}$ functions as an endocrine suppres- 
sor of renin biosynthesis and the subsequent genetic disruption of the VDR results in over-stimulation of the RAS, leading to high blood pressure and cardiac hypertrophy. The cardiac hypertrophy seen in vitamin D receptor knockout mice is a consequence of activation not only of the systemic, but also of the cardiac RAS [31]. These findings are confirmed by a recent paper published by Zhou et al. [29] who demonstrated that mutant mice deficient in $1,25(\mathrm{OH})_{2} \mathrm{D}_{3}$ biosynthesis develop hypertension, cardiac hypertrophy, and impaired cardiac systolic function due to the over-stimulation of the renal and cardiac RAS.

Not all authors agree with this concept (see also below). Simpson et al. [33] found that vitamin D deficiency indeed induces myocardial hypertrophy and extracellular matrix production and deposition in the myocardial tissue of the rats; trichrome staining of heart tissue showed marked increase in fibrotic lesions in vitamin $\mathrm{D}$ receptor knockout (VDR-KO) mice. However, analysis of plasma renin activity, angiotensin-II and aldosterone levels showed elevated but not significantly different renin activity in knockout mice versus normal mice and no significant differences in angiotensin-II or aldosterone levels $[33,34]$. These finding suggest therefore that there may be renin-independent associations between vitamin $\mathrm{D}$ and cardiac structure.

\section{Other Effects of Vitamin D Therapy on Cardiac Structure and Function}

Vitamin D also has several direct effects on cardiac tissue growth and development including increased collagen deposition, hypertrophy, and hyperplasia.

Zitterman et al. [35] described that an increased serum level of atrial natriuretic peptide (ANP) gene expression is one of the earliest and most reliable markers of cardiac hypertrophy in neonatal rat cardiac myocytes. In patients with LVH, virtually every biochemical or physical perturbation that results in 'hypertrophy' (increased cell size, increased protein synthesis, and reorganization of sarcomeric structure) also leads to activation of ANP gene expression and a reduced circulating level of calcitriol, indicating an inverse relationship between vitamin D level and cardiac hypertrophy [35].

These clinical findings are also supported by previous animal and in vitro studies that provide alternative potential explanations. In rats, Weishaar et al. [36] showed that vitamin $\mathrm{D}$ deficiency induced myocardial hypertrophy (increased heart weight/body weight ratio) and ex- tracellular matrix production via increased c-myc protein levels. Conversely, Gardner's group found that calcitriol inhibited myocyte hypertrophy and the expression of actin and ANP, markers of myocardial hypertrophy; these later findings were confirmed in $\mathrm{Wu}$ et al. [37] where it was found in vitro that $1,25(\mathrm{OH})_{2} \mathrm{D}_{3}$ inhibited endothelin-induced myocyte hypertrophy and the expression of skeletal actin and ANP genes. More recently, Nibbelink et al. [38] demonstrated that $1,25(\mathrm{OH})_{2} \mathrm{D}_{3}$ increases expression of myotrophin (myotrophin is a myocardial hypertrophy-inducing factor initially documented in cardiomyopathic hearts).

Extracellular matrix remodeling, mediated by matrix metalloproteinase, may be involved in progressive LV remodeling, dilatation, and heart failure. Rahman et al. [39] demonstrated that tissue inhibitors of metalloproteinase were significantly underexpressed in VDLKO mice; in the same animal model, the heart myofibrils showed highly significant cellular hypertrophy and the fibrotic lesions were increased [39]. In humans, in an Indo-Asian population, apparently healthy, but with endemic vitamin D deficiency, plasma metalloproteinase levels were inversely related to vitamin D status [40]. One year later, after treatment with vitamin D, mean plasma metalloproteinase levels were decreased significantly. Overproduction of transforming growth factor- $\beta$ (TGF- $\beta$ ) is almost universally observed in models of experimental renal failure and it is recognized to play a crucial role in renal fibrogenesis; conversely, a blockade of its activity is associated with attenuation of progressive renal failure. There is ample evidence that TGF- $\beta$ stimulates the synthesis of many extracellular matrix components while reducing collagenase production, as VDR activation is associated with reduced expression of vascular endothelial growth factor (VEGF) and TGF- $\beta$. Angiotensin-II, the major effector molecule of the RAS, has also been strongly implicated in renal fibrosis. Numerous experimental studies, as well as clinical studies, have shown that angiotensin-II blockade reduces renal injury and fibrosis in part by reducing TGF$\beta$. Cell culture studies have convincingly demonstrated that angiotensin-II directly stimulates transcription and bioactivation of TGF- $\beta$ [42] as well as the synthesis of VEGF in podocytes, which is mediated, in part, through the activation of the p38 mitogen-activated protein kinase pathway [42]. However, angiotensin-II blockade does not normalize TGF- $\beta$ levels, and disease progression is slowed, but not halted. 


\section{Inflammation and Vitamin D}

Inflammation is strongly associated with increased morbidity and mortality in CKD. Pro-inflammatory cytokines, tumor necrosis factor (TNF)- $\alpha$ and interleukin (IL)-1 or IL-6 (the central regulator of the inflammatory process) are elevated in CKD. Activated vitamin D has potent anti-inflammatory effects, by reducing production of the T-helper type 1 cytokines, IL-2, interferon- $\gamma$, and TNF- $\alpha$ and by suppression of inflammatory macrophage reactions [43]. Cytokine production may be modulated by calcitriol either as a result of its direct interaction with monocytes or indirectly through its effect on calcium and PTH metabolism. Panichi et al. [44] indicated a dose-dependent in vitro inhibition of the IL- $1 \beta$ and TNF$\alpha$ production in uremic subjects incubated with physiologic doses of calcitriol. Therapeutic doses of calcitriol are also able to induce a marked decrease of cytokine production in vivo. Vitamin D deficiency is associated with elevated levels of C-reactive protein (CRP), and supplementation of this vitamin led to a $23 \%$ reduction in CRP levels at 1 year in a healthy cohort [45]. Alborzi et al. found the same relationship in their recent study [46]. All of their study subjects were vitamin D deficient $(<30 \mathrm{ng} / \mathrm{ml})$ and $60 \%$ also had an elevated baseline high-sensitivity CRP level, indicating subclinical inflammation. This study showed a reduction in CRP levels within 1 month after treatment with paricalcitol in patients with CKD. In contrast, in another recent paper, Ewers et al. [47] examined the connection between vitamin D status and lowgrade systemic inflammation (serum concentrations of CRP) in an adult population of kidney-transplant patients. No impact of vitamin D status on low-grade systemic inflammation was found [47].

Many studies have demonstrated that vitamin D is a potent suppressor of cell proliferation and an inductor of the differentiation in numerous cells types [48]. The antiproliferative action is mediated predominantly through a G1/S block of the cell cycle. However, there are comparatively fewer studies which have analyzed the effects of vitamin $\mathrm{D}$ on vascular smooth muscle cell (VSMC) proliferation, and the results of these are rather different. Cardus et al. [49] found that calcitriol induced a dose-dependent increase in VSMC proliferation (achieved by shortening the G1 phase). This effect is mediated by VEGF. This study was performed in vitro, and the concentration of $1,25(\mathrm{OH})_{2}$-vitamin $\mathrm{D}$ was significantly higher than the normal serum level, suggesting that $1,25(\mathrm{OH})_{2}$-vitamin D overdosing may cause stimulation of VSMC proliferation [37]. In contrast, O'Connell et al.
[50] showed that $1,25(\mathrm{OH})_{2} \mathrm{D}_{3}$ deficiency produced hyperplasia and increased c-myc protein levels in the hearts of vitamin $\mathrm{D}_{3}$-deficient rats. The mechanism by which $1,25(\mathrm{OH})_{2} \mathrm{D}_{3}$ regulates myocyte proliferation involves blocking entry into the $S$ phase of the cell cycle [49].

Vitamin D plays also an important role in cardiac function. Cardiac muscle cells possess a VDR and calcitriol-dependent $\mathrm{Ca}^{2+}$ binding protein. In a recent observational study in patients with cardiac dysfunction, both vitamin $\mathrm{D}$ deficiency and hyperparathyroidism were common findings. Moreover, a calcitriol-mediated rapid activation of voltage-dependent $\mathrm{Ca}^{2+}$ channels exists in cardiac muscle cells, and the uptake of calcium by cardiac muscle cells is in part regulated by vitamin $D_{3}$. In experimental studies, vitamin $\mathrm{D}$ administration can normalize the impaired contractility of the myocardium. Baksi et al. [51] observed an increased contractility in response to increasing concentration of the extracellular calcium bath in atria in rats maintained on a vitamin Ddeficient diet. The direct effects of vitamin $\mathrm{D}$ deficiency were suggested by Weishaar et al. [36]: rats fed a vitamin D-deficient diet have increased amounts of collagen (quantified by measuring hydroxyproline per gram of heart tissue and collagen deposition in the extracellular space of the myocardium). This effect could not be suppressed by normocalcemia, suggesting that indeed this is a direct action/consequence of vitamin $\mathrm{D}$ deficiency [51].

\section{Vitamin D and Arterial Stiffness}

Arterial stiffness in uremic patients is increased and arterial/coronary calcifications are frequent. Increased arterial stiffness is a consequence of several factors, including chronic fluid overload, the state of chronic microinflammation, sympathetic overactivity, activation of the renin-angiotensin-aldosterone axis, advanced glycation end products, lipid peroxidation, abnormalities of the nitric oxide system, and not the least, the calcification of the vessel wall. Arterial calcification is closely related to arterial stiffness: more calcified arteries are obviously losing their elastic properties [52]. Increased arterial calcification and stiffness may at least in part explain the very high morbidity and mortality in end-stage renal disease patients.

A passive process is implicated in vascular calcification, i.e. calcium-phosphate precipitation in the vessel walls, associated with an active biological process, 'ossification' of the vascular wall structure. Important con- 
tributors to these calcifications are hyperphosphatemia and an increased calcium-phosphate product $\left(>55 \mathrm{mg}^{2} /\right.$ $\mathrm{dl}^{2}$ ). At the same time, high levels of phosphate and/or calcium directly activate genes associated with osteoblastic functions in the smooth muscle cells (e.g. bone matrix protein $7, \alpha 2-\mathrm{HS}$ glycoprotein, and matrix GLA protein) [53].

The first logical approach for reducing vascular calcification is the appropriate handling of the calcium-phosphate metabolism. Currently used calcium-containing phosphate binders (like calcium carbonate or acetate) may promote vascular calcification. Non-calcium containing phosphate binders (like sevelamer hydrochloride or lanthanum carbonate) may reduce the calcium-load in dialysis patients [54]. In some in vitro studies and in animal models, calcitriol has induced vascular calcification, by oversuppression of PTH and induction of a low-turnover bone disease state, or by increased calcium-phosphorus $(\mathrm{Ca} \times \mathrm{P})$ product [55]. Vitamin D analogues (paricalcitol, doxercalciferol, maxacalcitol) are capable of effective parathyroid suppression; they are structurally modified for fewer calcemic and phosphatemic effects. In a very recent study, Cardus et al. [56] demonstrated that paricalcitol has different effects on vascular calcification compared with calcitriol. Both compounds raised the serum calcium and $\mathrm{Ca} \times \mathrm{P}$ product compared to control, but only calcitriol caused an increase in the calcification of the abdominal aorta. Similar results were observed by Hirata et al. [57].These results support the fact that different VDR activators exert differential effects on vascular calcification independent of serum calcium, phosphorus and $\mathrm{Ca} \times \mathrm{P}$ product.

Recently, Noohan et al. [58] demonstrated that paricalcitol and doxercalciferol display differential effects on aortic calcification, independent of serum $\mathrm{Ca}, \mathrm{P}$ and $\mathrm{Ca}$ $\times$ P. These finding suggest a different mechanism of action between these 2 VDRA activators. The mechanism for the differential effects remains unclear [58].

\section{Vitamin D, PTH and LVH}

The function of vitamin $\mathrm{D}$ is accomplished in close coordination with the PTH. Vitamin D deficiency triggers hyperparathyroidism, which itself tends to promote cardiac hypertrophy.

In vitro, there are several possible explanations for increased LVM in primary/secondary hyperparathyroidism. PTH acts on adult cardiomyocytes by binding to the $\mathrm{PTH} / \mathrm{PTHrP}$ receptor, inducing a rise in calcium intra- cellular levels [60], activating protein kinase $C$, which activates hypertrophic pathways inside the cell [61]. Expression of some cardiac proto-oncogenes may be enhanced, which may lead to altered expression of several genes involved in cardiac structure and function, and may stimulate the translation of contractile and non-contractile cardiac muscle proteins, all leading to LVH [62]. Additionally, Amann et al. [63] showed that elevated PTH levels cause irreversible interstitial fibrosis with collagen deposition. Regarding the relationship between PTH and systolic function, a direct effect of PTH on myocardial contractility has not been demonstrated in adult human myocytes, but the intracellular influx of calcium induced by PTH has been shown to increase contractility in animal cells.

In patients with primary hyperparathyroidism, there are conflicting reports on the relation between PTH and $\mathrm{LVH}$, as well as on the cardiac effects of parathyroidectomy in these patients. Stefenelli et al. [64] reported that $81.6 \%$ of patients with primary hyperparathyroidism (PHPT) had hypertrophy of the intraventricular septum. Längle et al. [38] found that $50 \%$ of the patients with PHPT had LVH. Piovesan et al. [65] found a correlation between PTH values and LVMI; this correlation suggests an action of the hormone in the pathogenesis of LV hypertrophy, confirmed also by the decrease of LVMI after the reduction of PTH levels. Some studies have not detected any cardiac hypertrophy in PHPT patients [66], but in general these included fewer patients with a shorter duration of hyperparathyroidism.

The increased prevalence of LVH seems to be independent of blood pressure, since cardiac hypertrophy is also a common finding in normotensive PHPT patients. Furthermore, Stefenelli et al. [64] found that only $55 \%$ of the recruited PHPT patients with LVH had a history of hypertension. In the subgroup of patients who were receiving antihypertensive treatment, parathyroidectomy was not followed by a reduction of $\mathrm{LVH}$; whilst in patients without evidence of hypertension there was a significant reduction of LVH [64].

In dialysis patients with secondary hyperparathyroidism, several investigators have shown a relationship between PTH and LVH. Strózecki et al. [67] showed that the LVM was significantly greater in patients with remarkably high plasma PTH levels. Some studies have reported an improvement of cardiac function after parathyroid treatment in dialysis patients. For example, parathyroidectomy in 12 patients on maintenance HD resulted in a $22 \%$ reduction in LVMI [68]. However, Fujii et al. [73] consider that in dialysis patients many factors (such as 
hypertension, anemia and volume overload, calcium and phosphate levels) may influence the cardiac abnormalities observed in these patients, so that it is very difficult to evaluate the relative importance and relationship between all these competing factors. None of the studies account for all these potentially relevant factors. The only study that performed load- and rate-independent measurement of cardiac function before and after parathyroid treatment under identical conditions was made by Fellner et al. [69] and included only 7 stable hemodialysis patients; it did not find a direct effect of PTH on cardiac function. Further interventional studies are clearly necessary to clarify the contribution of these factors to $\mathrm{LVH}$ in dialysis patients.

\section{Calcitriol or Newer Vitamin D Analogues?}

Vitamin D therapy has intrinsic dose-dependent calcemic and phosphatemic properties. This has heightened interest in structurally modified derivatives, with the hope that these unwanted effects will be reduced.

Although early reports indicated less increase in serum calcium and phosphorus at 12 months, and a significantly higher survival over the 36 months with vitamin $\mathrm{D}$ analogues (e.g. paricalcitol) compared to calcitriol [70], more recent trials are less positive. The Current Caring for Australians with Renal Impairment guidelines for CKD stage 5, published in 2006, indicated that there is insufficient evidence to support the superiority of newer vitamin D analogues over calcitriol [71]. Palmer et al. [72] using the 76 available randomized trials, found no evidence for the superiority of newer vitamin $\mathrm{D}$ analogues over established vitamin D compounds, for any major outcome.

Although promising, the survival benefit of the newer vitamin D analogues needs more evaluation, and must be subjected to the full rigor of an independently-monitored hard end-point outcome trial.

\section{Conclusion}

Effects of vitamin D compounds are necessarily pleiotropic as VDRs exist in almost every tissue and are incompletely understood. Vitamin D is an important influencing factor in the development and physiology of cardiac tissue. In dialysis patients, clinical studies suggest improvement in survival after treatment with vitamin $\mathrm{D}$ and a beneficial effect on LVH. These can be achieved by negatively regulating the RAS, modulating the inflammatory response to blood vessel injury, as well as inhibiting cardiomyocyte hypertrophy and proliferation. Nevertheless, definitive proof is still lacking, and in an era of mostly negative clinical trials, and ever-increasing pressure on health-care budgets, evidence derived from a solid, prospective, randomized controlled trial is mandated. However, the growth of basic scientific, observational, and interventional research in this field is explosive and is likely to lead to therapeutic advances in the next decade.

\section{References}

1 Foley RN, Parfrey PS, et al: Serial change in echocardiographic parameters and cardiac failure in end-stage renal disease. J Am Soc Nephrol 2000;11:912-916.

-2 Levin A, Singer J, Thompson CR, Ross H, Lewis M: Prevalent left ventricular hypertrophy in the predialysis population: identifying opportunities for intervention. Am J Kidney Dis 1996;27:347-354.

- 3 Tucker B, Fabbian F, Giles M, Thuraisingham RC, Raine AE, Baker LR: Left ventricular hypertrophy and ambulatory blood pressure monitoring in chronic renal failure. Nephrol Dial Transplant 1997;12:724-728.

-4 Foley RN, Parfrey PS, Kent GM, Harnett JD, Murray DC, Barre PE: Long-term evolution of cardiomyopathy in dialysis patients. Kidney Int 1998;54:1720-1725.
5 Levin A, Thompson CR, Ethier et al: Left ventricular mass index increase in early renal disease: impact of decline in hemoglobin. Am J Kidney Dis 1999;34:125-134.

6 Tian JP, Wang T, Wang H, Cheng LT, Tian XK, Lindholm B, Axelsson J, Du FH: The prevalence of left ventricular hypertrophy in Chinese hemodialysis patients is higher than that in peritoneal dialysis patients. Ren Fail 2008;30:391-400.

7 London GM, Pannier B, Guerin AP, Blacher J, Marchais SJ, Darne B, Metivier F, Adda H, Safar ME: Alterations of left ventricular hypertrophy in and survival of patients receiving hemodialysis: follow-up of an interventional study. J Am Soc Nephrol 2001;12: 2759-2767.

8 Foley RN, Parfrey PS, Morgan J, et al: Effect of hemoglobin levels in hemodialysis patients with asymptomatic cardiomyopathy. Kidney Int 2000;58:1325-1335.
9 Covic A, Mardare NG, Ardeleanu S, Prisada O, Gusbeth-Tatomir P, Goldsmith DJ: Serial echocardiographic changes in patients on hemodialysis: an evaluation of guideline implementation. J Nephrol 2006;19:783-793.

10 Shoji T, Shinohara K, Kimoto E, et al: Lower risk for cardiovascular mortality in oral 1hydroxy vitamin D3 users in a haemodialysis population. Nephrol Dial Transplant 2004; 19:179-184

11 Goldsmith DJ, Covic A, Sambrook PA, Ackrill P: Vascular calcification in long-term haemodialysis patients in a single unit: a retrospective analysis. Nephron 1997;77:37-43.

12 Shoji T, Nishizawa Y: Effects of vitamin D on non-classical target organs and survival. Clin Calcium 2007;17:691-697.

13 Baran DT, Quail JM, Ray R, Honeyman $\mathrm{T}$ : Binding of 1alpha,25-dihydroxyvitamin D(3) to annexin II: effect of vitamin D metabolites and calcium. J Cell Biochem 2000; 80:259-265. 
14 Adams JS, Hewison M: Unexpected actions of vitamin D: new perspectives on the regulation of innate and adaptive immunity. Nat Clin Pract Endocrinol Metab 2008;4:80-90.

-15 Froicu M, Weaver V, Wynn TA, McDowell MA, Welsh JE, Cantorna MT: A crucial role for the vitamin D receptor in experimental inflammatory bowel diseases. Mol Endocrin 2003;17:2386-2393.

16 Michos ED, Melamed ML: Vitamin D and cardiovascular disease risk. Curr Opin Clin Nutr Metab Care 2008;11:7-12.

-17 Holick MF, Chen TC: Vitamin D deficiency: a worldwide problem with health consequences. Am J Clin Nutr 2008;87:10801086.

-18 Thomas MK, Lloyd-Jones DM, Thadhani RI, Shaw AC, Deraska DJ, Kitch BT, Vamvakas EC, Dick IM, Prince RL: Hypovitaminosis D in medical inpatients. N Engl J Med 1998; 338:777-783.

-19 Lips P, Duong T, Oleksik A, Black D, Cummings S, Cox D, Nickelsen T: A global study of vitamin D status and parathyroid function in postmenopausal women with osteoporosis: baseline data from the multiple outcome of raloxifene evaluation trial. J Clin Endocrinol Metab 2001;86:1212-1221.

-20 Isaia G, Giorgino R, Rini GB, Bevilacqua M, Maugeri D, Adami S: Prevalence of hypovitaminosis D in elderly women in Italy: clinical consequences and risk factors. Osteoporos Int 2003; 14:577-582.

-21 Pilz S, März W, Wellnitz B, Seelhorst U, Fahrleitner-Pammer A, Dimai HP, Boehm BO, Dobnig H: Association of vitamin D deficiency with heart failure and sudden cardiac death in a large cross-sectional study of patients referred for coronary angiography. Clin Endocrinol Metab 2008;93:3927-3935.

-22 Poole KE, Loveridge N, Barker PJ, Halsall DJ, Rose C, Reeve J, Warburton EA: Reduced vitamin D in acute stroke. Stroke 2006;37:243245.

23 Giovannucci E, Liu Y, Hollis BW, Rimm EB: 25-Hydroxyvitamin $\mathrm{D}$ and risk of myocardial infarction in men: a prospective study. Arch Intern Med 2008;168:1174-1180.

-24 Hsia J, Heiss G, Ren H, Allison M, Dolan NC, Greenland P, Heckbert SR, Johnson KC, Manson JE, Sidney S, Trevisan M; Women's Health Initiative Investigators: Calcium/vitamin D supplementation and cardiovascular events. Circulation 2007;115:846-854.

$>25$ Wang TJ, Pencina MJ, Booth SL, Jacques $\mathrm{PF}$, Ingelsson $\mathrm{E}$, Lanier $\mathrm{K}$, Benjamin $\mathrm{EJ}$, D’Agostino RB, Wolf M, Vasan RS: Vitamin $\mathrm{D}$ deficiency and risk of cardiovascular disease. Circulation 2008;117:503-511.

26 Rosenthal T: Seasonal variations in blood pressure. Am J Geriatr Cardiol 2004;13:267273.

-27 Scragg R, Sowers M, Bell C: Serum 25-hydroxyvitamin $\mathrm{D}$, ethnicity, and blood pressure in the Third National Health and Nutrition Examination Survey. Am J Hypertens 2007;20:713-719.
28 Park CW, Oh YS, Shin YS, Kim CM, Kim YS, Kim SY, Choi EJ, Chang YS, Bang BK: Intravenous calcitriol regresses myocardial hypertrophy in hemodialysis patients with secondary hyperparathyroidism. Am J Kidney Dis 1999;33:73-81.

29 Li YC, Kong J, Wei M, Chen ZF, Liu SQ, Cao LP: 1,25-Dihydroxyvitamin $\mathrm{D}(3)$ is a negative endocrine regulator of the renin-angiotensin system. J Clin Invest 2002;110:229238.

30 Yuan W, Pan W, Kong J, Zheng W, Szeto FL, Wong KE, Cohen R, Klopot A, Zhang Z, Li YC: 1,25-Dihydroxyvitamin D3 suppresses renin gene transcription by blocking the activity of the cyclic AMP response element in the renin gene promoter. J Biol Chem 2007; 282:29821-29830.

31 Xiang W, Kong J, Chen S, Cao LP, Qiao G, Zheng W, Liu W, Li X, Gardner DG, Li YC: Cardiac hypertrophy in vitamin $\mathrm{D}$ receptor knockout mice: role of the systemic and cardiac renin-angiotensin systems. Am J Physiol Endocrinol Metab 2005;288:E125-E132.

32 Zhou C, Lu F, Cao K, Xu D, Goltzman D, Miao D: Calcium-independent and $1,25(\mathrm{OH})_{2} \mathrm{D}_{3}$-dependent regulation of the renin-angiotensin system in lalpha-hydroxylase knockout mice. Kidney Int 2008;74: 170-179.

33 Simpson RU, Hershey SH, Nibbelink KA: Characterization of heart size and blood pressure in the vitamin D receptor knockout mouse. J Steroid Biochem Mol Biol 2007;103: 521-524.

34 Nibbelink KA, Tishkoff DX, Hershey SD, Rahman A, Simpson RU: 1,25(OH)2-vitamin D3 actions on cell proliferation, size, gene expression, and receptor localization, in the HL-1 cardiac myocyte. J Steroid Biochem Mol Biol 2007;103:533-537.

35 Zittermann A, Schleithoff SS, Tenderich G, Berthold HK, Körfer R, Stehle P: Low vitamin D status: a contributing factor in the pathogenesis of congestive heart failure? J Am Coll Cardiol 2003;41:105-112.

-36 Weishaar RE, Kim SN, Saunders DE, Simpson RU: Involvement of vitamin D3 with cardiovascular function. III. Effects on physical and morphological properties. Am J Physiol 1990;258:E134-E142.

$37 \mathrm{Wu}$ J, Garami M, Cheng T, Gardner DG: 1,25(OH)2 vitamin D3, and retinoic acid antagonize endothelin-stimulated hypertrophy of neonatal rat cardiac myocytes. J Clin Invest 1996;97:1577-1588.

38 Längle F, Abela C, Koller-Strametz J, et al: Primary hyperparathyroidism and the heart: cardiac abnormalities correlated to clinical and biochemical data. World J Surg 1994;18: 619-624.

39 Rahman A, Hershey S, Ahmed S, Nibbelink K, Simpson RU: Heart extracellular matrix gene expression profile in the vitamin $\mathrm{D}$ receptor knockout mice. J Steroid Biochem Mol Biol 2007;103:416-419.
40 Timms PM, Mannan N, Hitman GA, Noonan K, Mills PG, Syndercombe-Court D, Aganna E, Price CP, Boucher BJ: Circulating MMP9, vitamin D and variation in the TIMP-1 response with VDR genotype: mechanisms for inflammatory damage in chronic disorders? QJM 2002;95:787-796.

41 Shihab FS, Bennett WM, Tanner AM, Andoh TF: Angiotensin II blockade decreases TGF $\beta$ and matrix proteins in cyclosporine nephropathy. Kidney Int 1997;52:660-673.

42 Kang YS, Park YG, Kim BK, Han SY, Jee YH, Han KH, Lee MH, Song HK, Cha DR, Kang SW, Han DS: Angiotensin II stimulates the synthesis of vascular endothelial growth factor through the p38 mitogen activated protein kinase pathway in cultured mouse podocytes. J Mol Endocrinol 2006;36:377338.

43 Helming L, Böse J, Ehrchen J, Schiebe S, Frahm T, Geffers R, Probst-Kepper M, Balling $\mathrm{R}$, Lengeling A: 1alpha,25-dihydroxyvitamin D3 is a potent suppressor of interferon gamma-mediated macrophage activation. Blood 2005;106:4351-4358.

44 Panichi V, De Pietro S, Andreini B, Bianchi AM, Migliori M, Taccola D, Giovannini L, Tetta C, Palla R: Calcitriol modulates in vivo and in vitro cytokine production: a role for intracellular calcium. Kidney Int 1998;54: 1463-1469.

45 Timms PM, Mannan N, Hitman GA, et al: Circulating MMP9, vitamin D and variation in the TIMP-1 response with VDR genotype: mechanisms for inflammatory damage in chronic disorders? QJM 2002;95:787796.

46 Alborzi P, Patel NA, Peterson C, Bills JE, Bekele DM, Bunaye Z, Light RP, Agarwal R: Paricalcitol reduces albuminuria and inflammation in chronic kidney disease: a randomized double-blind pilot trial. Hypertension 2008;52:249-255

47 Ewers B, Gasbjerg A, Moelgaard C, Frederiksen AM, Marckmann P: Vitamin D status in kidney transplant patients: need for intensified routine supplementation. Am J Clin Nutr 2008;87:431-437.

48 Ylikomi T, Laaksi I, Lou YR, et al: Antiproliferative action of vitamin D. Vitam Horm 2002;64:357-406.

49 Cardús A, Parisi E, Gallego C, Aldea M, Fernández E, Valdivielso JM: 1,25-Dihydroxyvitamin D3 stimulates vascular smooth muscle cell proliferation through a VEGF-mediated pathway. Kidney Int 2006; 69:1377-1384.

50 O'Connell TD, Berry JE, Jarvis AK, Somerman MJ, Simpson RU: 1,25-Dihydroxyvitamin D3 regulation of cardiac myocyte proliferation and hypertrophy. Am J Physiol 1997; 272: H1751-1758.

51 Baksi SN, Hughes MJ: Deficiency in dietary vitamin $\mathrm{D}$, not calcium, alters noradrenergic responsiveness in rat atria in vitro. J Mol Cell Cardiol 1986;18:653-656. 
\$2 Kullo IJ, Bailey KR, McConnell JP, et al: Aortic pulse wave velocity is associated with the presence and quantity of coronary artery calcium: a community-based study. Hypertension 2006;47:174-179.

53 Cozzolino M, Brancaccio D, Gallieni M, et al: Pathogenesis of vascular calcification in chronic kidney disease. Kidney Int 2005;68: 429-436.

54 Block GA, Spiegel DM, Ehrlich J, et al: Effects of sevelamer and calcium on coronary artery calcification in patients new to hemodialysis. Kidney Int 2005;68:1815-1824.

55 Wolisi, Godwin O, Moe MS: The role of vitamin $\mathrm{D}$ in vascular calcification in chronic kidney disease. Sem Dial 2005;18:307-314.

56 Cardus A, Panizo S, Parisi E, et al: Differential effects of vitamin D analogs on vascular calcification. J Bone Miner Res 2007;22:860866.

57 Hirata M, Katsumata K, Endo K, et al: In subtotally nephrectomized rats 22-oxacalcitriol suppresses parathyroid hormone with less risk of cardiovascular calcification or deterioration of residual renal function than $1,25(\mathrm{OH})_{2}$ vitamin $\mathrm{D}_{3}$. Nephrol Dial Transplant 2003; 18:1770-1776.

58 Noonan W, Nakane M, et al: Differential effects of vitamin D receptor activators on aortic calcification and pulse wave velocity in uraemic rats. Nephrol Dial Transplant 2008; 23:3824-3830.

59 Weishaar RE, Kim SN, Saunders DE, Simpson RU, et al: Involvement of vitamin D3 with cardiovascular function. III. Effects on physical and morphological properties. Am J Physiol 1990;258:134-142.
60 Smogorzewski M, Zayed M, Zhang YB, Roe J, Massry SG: Parathyroid hormone increases cytosolic calcium concentration in adult rat cardiac myocytes. Am J Physiol 1993;264: 1998-2006.

61 Schlüter KD, Weber M, Piper HM: Parathyroid hormone induces protein kinase $\mathrm{C}$ but not adenylate cyclase in adult cardiomyocytes and regulates cyclic AMP levels via protein kinase C-dependent phosphodiesterase activity. Biochem J 1995;310:439444.

62 Mall G, Rambausek M, Neumeister A, Kollmar S, Vetterlein F, Ritz E: Myocardial interstitial fibrosis in experimental uremia - implications for cardiac compliance. Kidney Int 1988;33:804-811.

63 Amann K, Ritz E, Wiest G, Klaus G, Mall G: A role of parathyroid hormone for the activation of cardiac fibroblasts in uremia. J Am Soc Nephrol 1994;4:1814-1819.

64 Stefenelli T, Abela C, Hebert F, et al: Cardiac abnormalities in patients with primary hyperparathyroidism: implications for followup. J Clin Endocrinol Metab 1997;82:106112.

65 Piovesan A, Molineri N: Left ventricular hypertrophy in primary hyperparathyroidism. Effects of successful parathyroidectomy. Clin Endocrinol (Oxf) 1999;50:321-328.

66 Nuzzo V, Tauchmanovà L, Fonderico F Trotta R, Fittipaldi MR, Fontana D, Rossi R, Lombardi G, Trimarco B, Lupoli G: Increased intima-media thickness of the carotid artery wall, normal blood pressure profile and normal left ventricular mass in subjects with primary hyperparathyroidism. Eur J Endocrinol 2002;147:453-459.
67 Strózecki P, Adamowicz A, Nartowicz E, Odrowaz-Sypniewska G, WlodarczykZ, Manitus J: Parathormon, calcium, phosphorus, and left ventricular structure and function in normotensive hemodialysis patients. Ren Fail 2001;23:115-126.

68 Chow KM, Szeto CC, Kum LC, et al: Improved health-related quality of life and left ventricular hypertrophy among dialysis patients treated with parathyroidectomy. J Nephrol 2003;16:878-885.

69 Fellner SK, Lang RM, Neumann A, Bushinsky DA, Borow KM: Parathyroid hormone and myocardial performance in dialysis patients. Am J Kidney Dis 1991;18:320-325.

$>70$ Teng M, Wolf M, Lowrie E, Ofsthun N, Lazarus JM, Thadhani R: Survival of patients undergoing hemodialysis with paricalcitol or calcitriol therapy. N Engl J Med 2003;349: 446-456.

71 Elder G, Faull R, Branley P, Hawley C: Caring for Australasians with Renal Impairment (CARI). The CARI guidelines. Management of bone disease, calcium, phosphate and parathyroid hormone. Nephrology (Carlton) 2006;11(suppl 1):230-261.

-72 Palmer SC, McGregor DO, Macaskill P, Craig JC, Elder GJ, Strippoli GF: Vitamin D compounds in chronic kidney disease. Ann Intern Med 2007;147:840-853.

73 Fujii H, Kim JI, Abe T, et al: Relationship between parathyroid hormone and cardiac abnormalities in chronic dialysis management. Intern Med 2007;46:1507-1512.

\title{
Editorial Comment
}

\author{
M. El Nahas, Sheffield
}

The minireview by Covic and colleagues from Guy's hospital in London, UK, draws the reader's attention to the recent literature suggestive of a survival advantage for vitamin $D$ in patients with end-stage renal disease (ESRD) on renal replacement therapy as well as in those with cardiovascular disease. It focuses on the cardiovascular benefits of vitamin D including its effect on vascular and cardiac remodelling. Whilst there is a considerable and rapidly expanding literature on the subject of vitamin $\mathrm{D}$ and survival advantage, readers should be critical in their appraisal of the literature as such survival benefit may be confounded by indication and case mix. The healthier patients may be given vitamin D supplementation. Readers should also be aware that a recent meta-analysis failed to show an advantage and that the DOPPS review showed that, whilst vitamin D was associated with a survival benefit in models prone to bias, no difference in mortality was observed in instrumental variable models that tend to be more independent of unmeasured confounding [1]. Clearly, a randomised control study of vitamin D supplementation in ESRD patients would be valuable. Whether such a clinical trial is feasible in such a patient group is doubtful in view of the established advantage of vitamin D supplementation on the management of renal osteodystrophy in these patients.

\section{Reference}

1 Tentori F, et al: The survival advantage for haemodialysis patients taking vitamin D is questioned: findings from the Dialysis Outcomes and Practice Patterns Study. Nephrol Dial Transplant 2009;24:963-972. 